\title{
AJUSTE ESTÉTICO EM FACETA DIRETA DE RESINA COMPOSTA
}

Aline Akemi MORI, Gabriela Cristina SANTIN, Guilherme BOSELLI, Edmara Tatiely Pedroso BERGAMO, Renata Corrêa PASCOTTO

A realização de facetas vestibulares em resina composta tem sido uma alternativa rotineiramente utilizada na clínica odontológica quando há a necessidade de se restaurar dentes anteriores com alteração de cor ou forma anatômica. Para a sua confecção o profissional deve realizar um correto diagnóstico e plano de tratamento. Também é necessário possuir habilidade manual, a fim de reproduzir detalhes anatômicos, nuances de cor e textura naturais, o que exige boa experiência clínica. $\mathrm{O}$ objetivo deste relato é apresentar o caso clínico da confecção de faceta direta em resina composta no dente 11 de um paciente que após traumatismo apresentou escurecimento coronário em função de calcificação distrófica da polpa. O trabalho salientará a etapa de ajuste estético (textura de superfície) para a reprodução dos detalhes anatômicos superficiais a fim de favorecer a estética, de forma que esta etapa possa ser realizada mesmo por profissionais iniciantes na área de estética. Quando corretamente indicada e executada, a técnica de confecção de faceta direta em resina composta é eficiente no sentido de restabelecer a estética dentária harmonizando o elemento tratado junto aos dentes adjacentes. 